\title{
KETERTARIKAN WALANG SANGIT (Leptocorisa oratorius F.) TERHADAP BEBERAPA BAHAN ORGANIK YANG MEMBUSUK
}

\author{
Solikhin ${ }^{1}$
}

\begin{abstract}
Attractiveness of Rice Bug (Leptocorisa oratorius F.) to Several Faunal Decaying Materials. An experiment was conducted in Yogyakarta from October 1996 to September 1997 to know (1) the attractiveness of adult male versus female rice stink bug in to decaying crab, (2) the attractiveness of the rice stink bug from the result of point- 1 to five decaying materials, and (3) the volatile compounds emitted by each decaying material. For the first objective, 50 rice stink bugs (sex ratio 1:1) were released into a preference test cage for one hour. Data was then analyzed with $\mathrm{X}^{2}$ at 1 and 5\%. For the second objective, five replicates of five different treatments were arranged in randomized completely block design. As many as 125 rice stink bugs were released into the central part of the cage consisting of five equal parts of attractants for one hour. Data of rice stink bug from each part was analyzed with Anova continued with Duncan's Test at 1 and 5\%.. Volatile compounds emitted by each material were captured based on the method of Gamliel and Stapleton (1993) then identified with gas chromatography mass spectrophotometry (GC-MS) and (or) capillary gas chromatography. The results were that: (1) adult male rice bug was significantly more attracted to that of female in response to sixth-day-decayingcrab, (2) adult male rice bug was most attracted to sixth-day-decaying cow blood compared to four others, and (3) volatile compounds emitted by those five materials were carbon dioxide, methanol, ethanol, aceton, dimethyl sulphide, dimethyl disulphide, ammonia, acetic acid, and an unidentified compound.
\end{abstract}

Kata kunci: Rice stink bug (Leptocorisa oratorius F.), preference test, volatile compounds

\section{PENDAHULUAN}

Sudah diketahui sejak lama bahwa walang sangit tertarik dengan bahan-bahan yang membusuk (Kalshoven, 1981), bahkan petani sudah banyak yang memanfaatkan untuk mengendalikan populasi walang sangit tersebut. Salah satu caranya adalah memasang bahan-bahan yang sedang membusuk seperti terasi, burus, kepiting, dan kotoran ayam ras (Suhardi, 1996) dan beberapa gulma air (Israel dan Rao cit. Srivastava dan Saxena, 1964) di dekat malai. Sampai saat ini belum diketahui mengapa walang sangit menyukai bahan-bahan tersebut, tetapi diduga hal ini diperantarai oleh senyawa volatil.

Identifikasi senyawa-senyawa volatil yang menarik serangga (hama) sangat penting dilakukan dalam rangka pengelolaan serangga hama (Heath et al., 1992). Usaha ini nantinya akan sangat penting dalam rangka pengelolaan hama terpadu yang tidak hanya bertumpu pada penggunaan pestisida sintetik organik. Tetapi salah satu hal yang perlu diperhatikan adalah keberadaan senyawa volatil (bau) dari tanaman atau bahan lainnya berada dalam keadaan campuran (Vinson, 1981). Schoonhoven (cit. Vinson, 1981) menyatakan bahwa faktor bau sering berada dalam kombinasi atau komposisi yang khas, berbeda antara satu tanaman atau bahan dengan yang lainnya. Bahkan Kamm dan Fronk (cit. Vinson, 1981) menemukan 95 macam senyawa yang berasal dari alfalfa dalam bentuk cairan atau terlarut. Setelah diteliti dalam kaitannya dengan reaksi serangga Bruchophagus roddi ternyata 38 senyawa berfungsi sebagai atraktan, 9 sebagai repelen, dan sisanya tidak menimbulkan reaksi sama sekali.

Ketertarikan beberapa spesies serangga terhadap senyawa volatil dipengaruhi oleh jenis kelaminnya. Sebagai contoh, ngengat betina Trichoplusia ni Hubner menyukai senyawa volatil fenilasetaldehid (Heath et al., 1992), 25 spesies dari genus Bactrocera (jantan) menyukai metil eugenol

\footnotetext{
${ }^{1}$ Dosen Jurusan Proteksi Tanaman, Fakultas Pertanian Universitas Lampung
} 
(Drew cit. Iwahashi, 1996), dan nyamuk betina serta beberapa serangga pengisap darah lainnya menyukai $\mathrm{CO}_{2}$ (Southwood, 1978). Sementara itu, walang sangit jantan dalam jumlah massal sering didapati mengumpul pada binatang yang membusuk dan beberapa gulma (Kalshoven, 1981).

Penelitian ini bertujuan untuk (1) melihat perbedaan ketertarikan walang sangit jantan dan betina dewasa terhadap kepiting yang membusuk, (2) melihat perbedaan ketertarikan walang sangit hasil poin-1 terhadap darah sapi, daging iga sapi, keong emas, bekicot, dan kepiting yang membusuk, dan (3) melihat komposisi dan macam senyawa-senyawa volatil yang dikeluarkan oleh kelima bahan di atas.

\section{METODE PENELITIAN}

\section{Tempat, Bahan, dan Alat}

Penelitian dilakukan di Dusun Dowangan, Banyuraden, Gamping, Sleman, Daerah Istimewa Yogyakarta ( $\pm 143 \mathrm{~m}$ dari permukaan laut) dari bulan Oktober 1996 sampai September 1997. Sedangkan identifikasi senyawa volatil dilakukan di Laboratorium Kimia Organik Fakultas Matematika dan Ilmu Pengetahuan Alam, Universitas Gadjah Mada.

Serangga uji yang digunakan, yaitu walang sangit (Leptocorisa oratorius F.) dewasa jantan dan betina umur 15 sampai 20 hari. Sedangkan bahan yang digunakan yaitu darah sapi, daging iga api, keong emas, bekicot, dan kepiting yang membusuk pada hari keenam. Bahan kimia yang digunakan untuk standar adalah asetaldehid, formaldehid, metanol, etanol, $\mathrm{CO}_{2}, \mathrm{NH}_{4} \mathrm{OH}$, aseton, dan asam asetat. Alat-alat yang digunakan yaitu kurungan serangga berukuran $6 \times 7 \times 2,5 \mathrm{~m}^{3}$ yang terbuat dari net plastik, alat hitung, kurungan uji berbentuk silinder dengan garis tengah 2,39 m dan tinggi $70 \mathrm{~cm}$ terbuat dari kaca acrylic dan mika transparan, jaring serangga, jarum syringe, ember plastik, sprayer kecil, polibag hitam, almari es, kawat kasa, stoples, termometer, termohigrometer, venojec plain silicone coated, kantung serangga, kipas angin, selang diameter 0,75 inchi, kaca, plastik mylar, mika, kamera, kaca pembesar, khromatografi gas kolom kapiler (HP 5890) Series II, dan kromatografi GC-MS Shimadzu.

\section{Uji Pendahuluan}

Uji ini dilakukan dengan tujuan untuk mengetahui hari keberapa pembusukan yang paling disenangi oleh walang sangit dengan menggunakan kepiting yang dibunuh secara mekanis (Solikhin dan Martono, 1997). Percobaan dilakukan di lapangan, yaitu pada petak pertanaman padi yang sedang masak susu, membujur arah utara-selatan. Kepiting yang membusuk (pembusukan satu sampai sebelas hari) dibungkus kain tile dan digantungkan setinggi malai padi pada jarak $3 \mathrm{~m}$. Pemasangan kepiting di lapangan dilakukan pada jam 16.00 kemudian pada jam 17.00 dilakukan penghitungan walang sangit yang mendatangi kepiting tersebut. Percobaan ini terdiri atas 11 perlakuan dan empat ulangan disusun dalam rancangan acak kelompok (RAK). Setelah diketahui hari pembusukan yang paling disenangi oleh walang sangit maka hasil tersebut digunakan sebagai dasar untuk uji empat bahan yang lain.

\section{Pembiakan Massal Walang Sangit}

Walang sangit dibiakkan secara massal dalam sungkup (kurungan) berukuran 6 × 7 × 2,5 $\mathrm{m}^{3}$ dengan menggunakan pertanaman padi yang sedang masak susu. Infestasi awal dilakukan dengan memasukkan 440 ekor walang sangit dewasa dengan nisbah kelamin 5 : 6 (Valencia dan Heinrich, 1982). Di dalam kurungan pemeliharaan terdapat 332 rumpun padi dengan empat perbedaan umur, dari masak susu sampai dengan yang sudah tua, sedangkan penggantian pakan dilakukan seminggu sekali. Berdasarkan metode di atas, setiap rumpun padi dapat digunakan oleh 22 ekor walang sangit (10 jantan dan 12 betina).

Walang sangit jantan dan (atau) betina sehat yang sudah memasuki instar terakhir (instar lima) dimasukkan ke dalam sungkup kecil dengan diameter $45 \mathrm{~cm}$ dan tinggi $97 \mathrm{~cm}$ yang berisi dua rumpun padi masak susu. Setiap sungkup atau kurungan berisi 25 sampai 30 ekor, dibiarkan hidup sampai dewasa sampai siap uji. Menurut Prijono (1988), pada umumnya serangga dewasa dengan perbedaan umur sekitar 7 hari dapat dikelompokkan kedalam satu grup (perlakuan) jika stadium dewasanya panjang.

\section{Uji Ketertarikan}

Semua uji ketertarikan walang sangit terhadap bahan penghasil senyawa volatil dilakukan dalam kurungan uji berbentuk silinder pada jam 16.00 sampai 17.00 (Solikhin dan Martono, 1997). Kurungan ini adalah hasil modifikasi dari kurungan uji preferensi (Dodge et al., 1990) yang dirancang untuk mengurangi terjadinya percampuran antar senyawa volatil dari bahan yang berbeda, yaitu 
dengan modifikasi terowongan angin atau wind tunnel dengan memasang kipas (Heath et al., 1992). Tanaman untuk hinggap adalah tanaman (malai) padi yang sedang masak susu untuk menciptakan kondisi lingkungan yang alami. Pada uji ketertarikan walang sangit dewasa jantan, lima macam bahan uji masingmasing seberat 50 gr terlebih dahulu dimasukkan ke dalam wadah dan ditutup rapat sebelum dimasukkan ke dalam kurungan uji secara acak dan berada pada jarak yang sama dengan poros kurungan uji dengan posisi menggantung. Sebanyak 125 ekor walang sangit dewasa jantan yang sebelumnya sudah berada pada bagian tengah kurungan uji dibiarkan memilih bahan uji yang disenangi. Setelah satu jam maka segera masing-masing jendela penyekat ditutup sehingga walang sangit terperangkap secara terpisah berdasarkan bahan yang diujikan. Perlakuan seperti ini dilakukan sebanyak lima ulangan sehingga didapatkan sebanyak 25 satuan percobaan (RAK). Ketertarikan walang sangit terhadap bahan uji diketahui dengan cara menghitung banyaknya walang sangit yang berada pada masing-masing bagian.

Uji ketertarikan walang sangit dewasa jantan dan betina dilakukan dengan cara yang hampir sama dengan uji ketertarikan, yaitu menggunakan bahan uji kepiting membusuk pada hari keenam. Pada uji ini seperlima bagian kurungan uji dibagi menjadi dua, satu bagian dekat dengan penghasil senyawa volatil dan yang lain dekat dengan poros. Walang sangit yang menuju bagian pertama berarti tertarik, sedangkan yang berada pada bagian kedua berarti kurang atau tidak tertarik. Walang sangit yang dilepaskan ke dalam kurungan uji berjumlah 50 ekor (nisbah kelamin $1: 1$ ).

\section{Identifikasi Senyawa Volatil}

Identifikasi senyawa volatil didahului dengan proses penangkapan senyawa volatil tersebut dengan memodifikasi metode dari Gamliel dan Stapleton (1993). Bahan uji yang telah membusuk pada hari

\section{HASIL DAN PEMBAHASAN}

\section{Uji Pendahuluan}

Hasil uji pendahuluan di lapangan yaitu berupa jumlah walang sangit yang tertangkap pada sebelas tingkat (hari) pembusukan kepiting disajikan pada Tabel 1. Pada hari keenam jumlah walang sangit tertangkap adalah yang paling banyak (berbeda nyata atau sangat nyata), berarti kepiting yang membusuk keenam masing-masing seberat 650 gr dimasukkan ke dalam stoples transparan kemudian ditutup rapat dengan cara menyegel atau melapisi masing-masing sambungan tutup stoples dengan selotip agar senyawa volatil tidak keluar dari sistem tersebut. Tutup stoples juga dilengkapi dengan dua lubang masing-masing untuk tempat termometer dan jarum syringe. Pada saat ditancapkan jarum syringe tersebut harus dalam keadaan kosong. Pengambilan senyawa volatil dilakukan pada siang hari antara pukul 14.00 sampai 15.00 dengan cara menarik kelep jarum syringe sebanyak $10 \mathrm{ml}$ kemudian secepatnya dimasukkan ke dalam tabung venojec hampa udara kapasitas $5 \mathrm{ml}$. Hal ini diulangi sehingga setiap tabung berisi senyawa volatil dengan tekanan yang jauh lebih tinggi daripada lingkungannya.

Untuk mengamankan senyawa volatil ini maka dilakukan penyimpanan di dalam lemari es. Senyawa volatil yang tertangkap diidentifikasi dengan metode GC-MS (gas chromatography-mass spectrophotometry) dan kromatografi kolom kapiler dengan cara menyuntikkannya sebanyak 2,5 ml. Cara yang sama juga dilakukan terhadap bahan kimia standar, dalam jumlah yang lebih sedikit (0,1 sampai $0,5 \mathrm{ml})$. Senyawa volatil yang dihasilkan kelima bahan diidentifikasi dengan mencocokkan waktu retensinya terhadap waktu retensi bahan standar.

\section{Analisis Data}

Data dari uji pendahuluan serta populasi walang sangit dewasa jantan yang tertarik pada masing-masing bahan uji dianalisis dengan Anova pada taraf nyata satu dan lima persen dilanjutkan dengan Uji Jarak Berganda Duncan yang Baru juga pada taraf yang sama (Steel dan Torrie, 1980). Sedangkan perbedaan ketertarikan walang sangit dewasa jantan dan betina terhadap bahan penghasil senyawa volatil diuji dengan uji Khi-Kuadrat $\left(\mathrm{X}^{2}\right)$ pada taraf nyata satu dan lima persen (Pollet dan Nasrullah, 1994).

pada hari keenam adalah yang paling disenangi oleh walang sangit. Walang sangit yang mendatangi semua perlakuan adalah walang sangit dewasa jantan.

Secara umum terlihat kehadiran walang sangit pada kepiting terus meningkat dari hari kesatu sampai keenam kemudian menurun sampai hari kesebelas. Kepiting yang baru saja dibunuh ternyata juga didatangi oleh walang sangit. Meningkatnya kehadiran walang sangit dari hari pertama sampai keenam mungkin disebabkan oleh semakin intensifnya 
pembusukan sehingga menghasilkan senyawa volatil (gas) yang semakin banyak jumlah atau macamnya. Hal yang sebaliknya terjadi dari hari ketujuh sampai kesebelas. Tanpa melihat jumlahnya, selain walang sangit serangga yang mendatangi kepiting yang membusuk pada hari keenam-diantaranya adalah dari familia Sarcophagidae, Mydidae, Acrididae, Eucantinae, Romaleinae, Tettigonidae, Alydidae, dan Pentatomidae. Ber-dasarkan jumlah jenis atau ordo serangga yang mendatangi kepiting yang membusuk mengisyaratkan bahwa kepiting tersebut mempunyai kemampuan daya tarik dengan spektrum yang lebar. Hal ini berbeda dengan feromon (semiokimia) yang mempunyai kemampuan daya tarik yang spesifik spesies (Fuchs dan Shroder, 1983). Meskipun demikian, ternyata jika kepiting sudah didatangi walang sangit (apalagi dalam jumlah yang banyak) maka serangga yang lainnya tidak ada yangmendatangi bahan tersebut. Keefektivan penggunaan atraktan untuk mengendalikan serangga memang harus memper-hatikan serangga lain yang menjadi pesaingnya (Klassen et al.; 1981; Heath et al., 1992).

\section{Ketertarikan Walang Sangit Dewasa Jantan dan Betina}

Hasil uji ketertarikan walang sangit dewasa jantan dan betina terhadap kepiting yang membusuk pada hari keenam disajikan dalam bentuk tabel kontingensi 2 x 2 (Tabel 2). Hasil penghitungan nilai $\mathrm{X}^{2}$ dengan menggunakan koreksi Yates (Pollet dan Nasrullah, 1994) sangat nyata dengan nilai 13,72. Maka dapat disimpulkan bahwa walang sangit yang tertarik terhadap bahan yang membusuk adalah hanya yang dewasa jantan saja. Hasil serupa juga didapatkan pada penelitian lapangan yang dilakukan oleh Sihono (1997). Pada uji pendahuluan ini sebenarnya pemasangan kepiting dan alatnya sudah dirancang untuk memungkinkan nimfa walang sangit juga mampu mendatangi kepiting.

Tabel 1. Rerata walang sangit tertangkap dari pukul 16.00 sampai 17.00 pada sebelas tingkat (hari) pembusukan kepiting*

$\begin{array}{ccc}\text { Hari } & \text { Walang } & \text { Simpangan } \\ \text { Pembusukan } & \text { Sangit } & \text { Baku }\end{array}$

Keterangan: * = Data sebelum ditransformasi, ** = Rerata dari empat ulangan, Angka yang diikuti oleh huruf yang sama tidak berbeda menurut Uji DNMRT pada taraf 1 dan $5 \%$

Tabel 2. Tabel kontingensi ketertarikan walang sangit jantan dan betina dewasa terhadap kepiting yang membusuk pada hari keenam

\begin{tabular}{lccc}
\hline $\begin{array}{c}\text { PosisiWalang } \\
\text { Sangit }\end{array}$ & Jantan & Betina & Jumlah \\
\hline Jauh dari Poros & 21 & 7 & 28 \\
Dekat Poros & 4 & 18 & 22 \\
Jumlah & 25 & 25 & 50 \\
\hline
\end{tabular}

Keterangan: $\quad$ Jauh $=$ Jauh dari poros (tertarik), Dekat $=$ Dekat poros (tidak tertarik)

\section{Ketertarikan Walang Sangit Dewasa Jantan terhadap Lima Bahan yang Membusuk}

Hasil pengujian ketertarikan walang sangit jantan terhadap lima bahan yang membusuk disajikan pada Tabel 3. Ternyata rerata walang sangit dewasa jantan paling banyak tertarik pada darah sapi $(39,4$ ekor) dan paling sedikit pada daging iga sapi $(12,0$ ekor), sedangkan yang mendatangi keong emas, kepiting, dan bekicot tidak menunjukkan perbedaan yang nyata.

Tabel 3. Rerata jumlah walang sangit dewasa jantan yang tertarik pada lima macam bahan yang membusuk pada hari keenam* 


\begin{tabular}{lcc}
\hline Perlakuan & $\begin{array}{c}\text { Walang Sangit } \\
\text { (ekor) }\end{array}$ & $\begin{array}{c}\text { Simpangan } \\
\text { Baku }\end{array}$ \\
\hline & & \\
Darah sapi & $39,4 \mathrm{a}$ & $\pm 8,32$ \\
Keong emas & $26,8 \mathrm{~b}$ & $\pm 3,35$ \\
Kepiting & $24,6 \mathrm{~b}$ & $\pm 7,16$ \\
Bekicot & $22,2 \mathrm{~b}$ & $\pm 6,99$ \\
Daging iga sapi & $12,0 \mathrm{c}$ & $\pm 6,32$ \\
& & \\
\hline
\end{tabular}

Keterangan: $*=$ Rerata dari data sebelum ditransformasi dengan akar kuadrat. Rerata yang diikuti oleh huruf yang sama tidak berbeda pada taraf nyata 1dan 5\% menurut Uji Jarak Berganda Duncan yang Baru.

Perbedaan jumlah walang sangit yang tertarik pada masing-masing bahan tersebut kemungkinan disebabkaan oleh adanya perbedaan komposisi atau macam senyawa volatil yang dihasilkan oleh masingmasing bahan yang sedang membusuk (Gambar 1). Selanjutnya terlihat pula bahwa jumlah atau macam senyawa volatil yang dihasilkan dan dapat dideteksi oleh kromatografi gas kolom kapiler berkisar antara enam sampai sembilan macam, paling banyak pada bekicot (9 macam). Kesembilan macam senyawa volatil tersebut satu diantaranya tidak dapat diidentifikasi dengan waktu retensi 12,152 menit. Sedangkan senyawa yang dapat diidentifikasi adalah karbon dioksida, metanol, etanol, aseton, dimetil sulfida, amoniak, asam asetat, dan dimetil disulfida.

\section{Pembahasan}

Senyawa volatil yang dihasilkan oleh kelima bahan yang membusuk berkisar antara enam sampai sembilan macam dengan suhu maksimum $34^{\circ} \mathrm{C}$ (pada hari pengamatan). Menurut Ahmad (1996), salah satu penyebab terjadinya perbedaan macam senyawa volatil adalah faktor suhu, selain bahan atau macam sumbernya. Hasil percobaannya membuktikan bahwa dengan suhu maksimum $40^{\circ} \mathrm{C}$ residu kubis yang mendapat perlakuan solarisasi menghasilkan lima macam senyawa volatil. Sedangkan hasil percobaan Gamliel dan Stapleton (1993) dengan suhu maksimum $60^{\circ} \mathrm{C}$ menghasilkan sebelas macam senyawa volatil. Kesebelas senyawa volatil tersebut adalah karbon dioksida asetaldehid, metanetiol, etanol, formaldehid, dimetil sulfida, dimetil disulfida, allilisotiosianat, dan tiga lainnya tidak teridentifikasi. Sedangkan lima macam senyawa volatil hasil percobaan Ahmad (1996) adalah metanol, etanol, asetaldehid, formaldehid dan satu lagi tidak teridentifikasi.

Pada Gambar 1 terlihat tiga bahan yaitu darah sapi, kepiting, dan daging iga sapi menghasilkan enam macam senyawa volatil yaitu karbon dioksida, metanol, dimetil sulfida, amoniak, asam asetat, dan dimetil disulfida, tetapi dengan persentase yang berbeda. Secara umum terlihat metanol merupakan senyawa volatil yang paling dominan dan $\mathrm{CO}_{2}$ sebaliknya. Pada keong emas kandungan $\mathrm{CO}_{2}$ adalah tertinggi dibandingkan empat bahan yang lainnya. Hal ini mengakibatkan senyawa volatil yang dilepaskan oleh keong emas paling cepat menyebar (terdispersi) dibandingkan dengan yang lainnya karena volatilitas $\mathrm{CO}_{2}$ paling tinggi. Salah satu tanda tingginya kandungan senyawa dengan volatilitas tinggi (yaitu $\mathrm{CO}_{2}$ dan metanol) adalah jika jarum syringe ditancapkan pada alat penangkap senyawa volatil maka kelep syringe tertekan keluar dengan cepat, sebagai contoh pada sampel keong emas dan kepiting. Volatilitas senyawa hasil identifikasi dapat dilihat waktu retensinya, semakin besar nilainya maka volatilitasnya semakin rendah. 


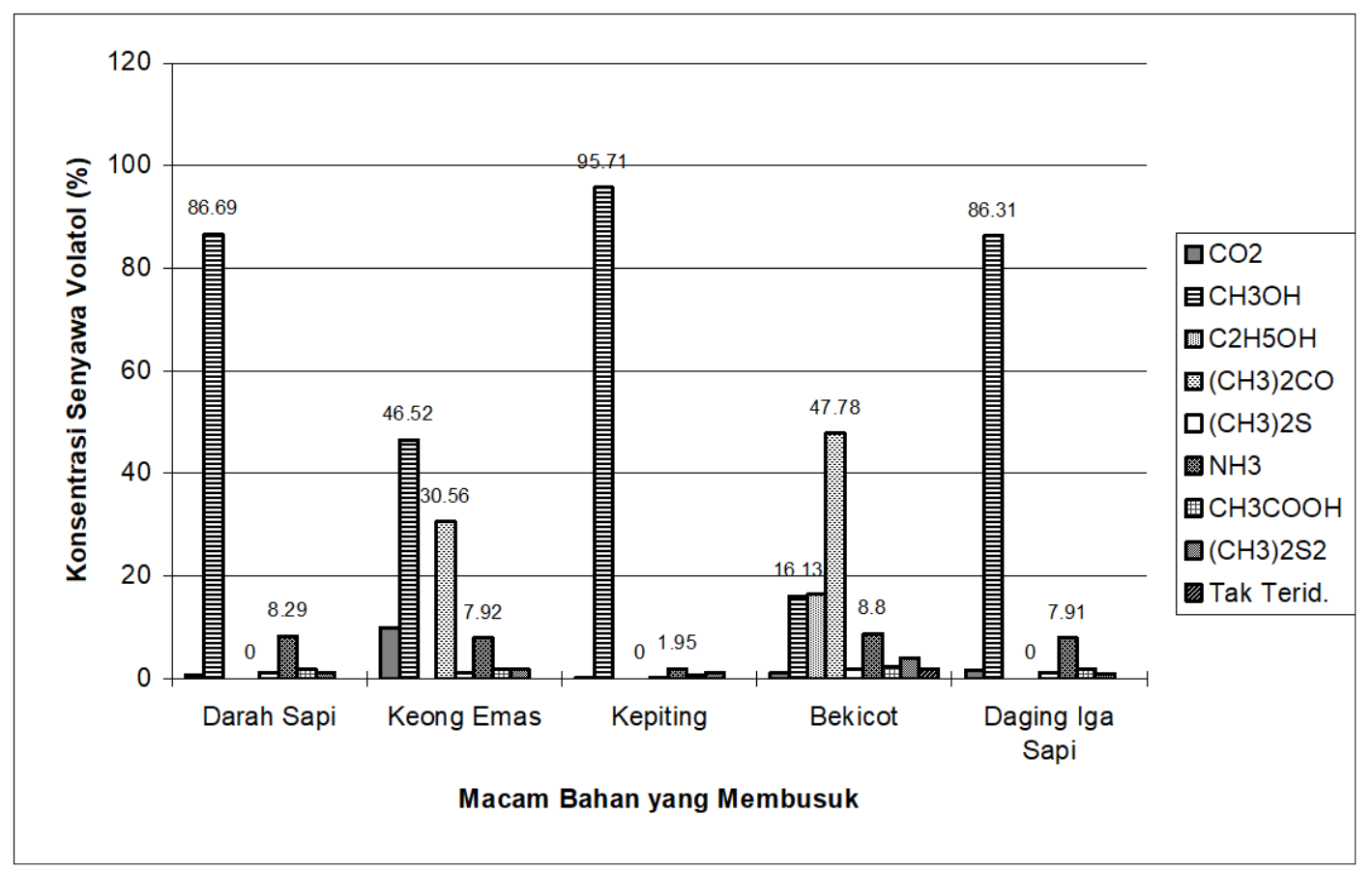

Gambar 1. Komposisi dan jenis senyawa volatil yang dikeluarkan oleh lima bahan yang sedang membusuk

Hasil menarik ditunjukkan oleh komposisi senyawa volatil pada darah sapi dan daging iga sapi dalam kaitannya dengan jumlah walang sangit jantan yang tertarik. Daging iga sapi yang digunakan adalah hasil dari penyembelihan yang salah satu tujuannya adalah untuk mengeluarkan darah sebanyakbanyaknya dari tubuh hewan yang disembelih. Tetapi dari hasil identifikasi ternyata kedua bahan ini

mengandung jenis senyawa volatil dalam jumlah yang sama yaitu enam macam dan komposisinya juga tidak terlalu jauh berbeda, kecuali karbon dioksida. Berarti daging iga sapi masih mengandung darah (darah yang tidak megalir) sehingga mempengaruhi hasil identifikasi.

Ada setidaknya empat hal yang mungkin menjadi penyebab sehubungan dengan perbedaan ketertarikan walang sangit terhadap komposisi senyawa volatil yang dihasilkan oleh darah sapi dan daging iga sapi.

Pertama; kandungan karbon dioksida $\left(\mathrm{CO}_{2}\right)$ yang lebih rendah pada darah sapi (0,73 persen) menyebabkan senyawa-senyawa volatil yang dikeluarkan oleh darah sapi relatif kurang cepat bergerak dibandingkan dengan senyawa-senyawa volatil yang dihasilkan oleh daging iga sapi. Hal ini akan menyebabkan konsentrasi di sekitar bahan menjadi relatif lebih tinggi. Sifat senyawa volatil salah satu diantaranya adalah penyebarannya cepat (Fries cit. Linderman dan Gilbert, 1975).

Kedua; mungkin ada senyawa-senyawa volatil lain yang konsentrasinya rendah atau terlalu rendah sehingga tidak terdeteksi apalagi teridentifikasi. Keberadaan senyawa senyawa volatil tersebut sangat penting jika walang sangit menyenangi senyawa volatil tersebut. Menurut Kaissling ( cit. Frazier, 1985), serangga mampu mengindera (merasa) senyawa volatil dengan ambang yang ekstrim rendah, bahkan paling rendah di antara semua binatang. Sebagai contoh ngengat Gypsy jantan mampu mengindera 9-37 kali lipat terhadap cis-7,8-epoxy-2methyl octadecane atau lebih dikenal dengan diplure daripada feromon alaminya pada konsentrasi 2 x 10 gram per liter.

Ketiga; komposisi senyawa volatil yang dikeluarkan oleh kedua bahan (darah sapi dan daging iga sapi) tidak jauh berbeda, tetapi salah satu yang harus diperhatikan adalah kemungkinan adanya kandungan isomer (optis atau geometrik). Kandungan isomer geometrik ini walaupun rendah akan sangat berpengaruh terhadap ketertarikan serangga (Kaissling cit. Frazier, 1985). Lebih lanjut Roelofs (1981) menyatakan bahwa spesifitas berbagai 
macam spesies dipengaruhi oleh penggunaan gugus fungsi dan isomer optis yang berbeda. Sejalan dengan hal ini Martono (1994) menyatakan bahwa kemurnian bahan uji adalah salah satu hal yang harus diperhatikan dalam uji hayati.

Keempat; senyawa-senyawa volatil yang menarik bagi walang sangit berada dalam konsentrasi atau komposisi tertentu. Jika konsentrasi atau komposisinya berubah kemungkinan fungsinya juga berubah, menjadi penolak atau repelen misalnya (Kaissling cit. Frazier, 1985) atau secara umum sebagai alat bertahan (Lockwood dan Story, 1987).

Fungsi masing-masing senyawa volatil sebagai atraktan baik secara tunggal maupun bersamasama (kolektif) sudah dilaporkan oleh banyak peneliti. Sebagai misal karbon dioksida digunakan sebagai penarik bagi serangga pengisap darah yaitu nyamuk betina dan lalat tse-tse (Southwood, 1978). Macrocheles muscaedomestica tertarik pada konsentrasi rendah amoniak dan skatole untuk menemukan habitatnya (Jalil dan Rodriguez cit. Greany dan Hagen, 1981). Selanjutnya disebutkan bahwa mangsa bagi macrochelid ini sering terdapat pada tempat (habitatnya) yaitu pada pupuk kandang yang mengeluarkan amoniak dan skatole sebagai hasil perombakan protein. Senyawa sulfida hasil perombakan asam amino mudah dikenal karena dicirikan oleh baunya yang sangat menyengat dan mudah menguap (Robinson, 1991). Beberapa disulfida dilaporkan berfungsi sebagai atraktan bagi serangga (Boscher cit. Robinson, 1991). Dimetil sulfida dan dimetil disulfida hasil dalam penelitian ini mungkin dapat berfungsi sebagai atraktan bagi walang sangit.

Bermacam-macam produk fermentasi jamur Monilia fructicola yaitu asetaldehid, etanol, dan asam asetat dilaporkan menarik bagi Biosteres (Opius) longicaudatus (Greany et al. cit. Vinson, 1981). Dijelaskan pula bahwa asetaldehid sebagai hasil oksidasi etanol ternyata 50 kali lebih aktif daripada etanol, sedangkan asam asetat jauh kurang aktif. Madden dan Spadbery (cit.Weseloh, 1981) menyatakan bahwa jamur simbiotik yang hidup pada kotoran inangnya yaitu Amylostereum sp. menyebabkan parasitoid datang dan menggali feces tersebut untuk mendapatkan ekstrak air, metanol, etanol, dan aseton dari jamur tersebut.

Ketertarikan walang sangit dewasa jantan terhadap senyawa volatil hasil proses pembusukan kelima bahan uji mungkin bukan berarti bahwa walang sangit membutuhkan senyawa volatil tersebut untuk digunakan sebagai nutrien, tetapi senyawa volatil tersebut berfungsi sebagai isyarat (cues) kimia untuk menemukan sumbernya, yaitu kelima bahan yang membusuk. Sesudah sampai pada lima bahan yang membusuk ternyata walang sangit memang segera menusukkan stiletnya kedalam bahan-bahan tersebut. Hasil penelitian menunjukkan banyak parasitoid menggunakan senyawa kimia yang dikeluarkan oleh serangga inangnya untuk menemukan habitat inangnya (Arthur cit. Nordlund, 1981).

Pemanfaatan lebih lanjut hasil penelitian ini mempunyai masa depan yang baik dalam rangka pengendalian hama secara terpadu (PHT), misalnya jika dibandingkan dengan teknik jantan mandul dengan berbagai macam kendalanya. Pada teknik ini, salah satu hal yang harus diperhatikan adalah penggunaan zat kimia pemandul yang efektif selalu menunjukkan daya kerja mutasi (mutagenic action) baik pada manusia maupun hama (Oka, 1996). Bahkan Metcalf dan Metcalf (cit. Oka, 1996) tidak merekomendasikan zat kimia pemandul digunakan dalam PHT.

\section{KESIMPULAN DAN SARAN}

Hasil uji pendahuluan menunjukkan bahwa kepiting yang membusuk pada hari keenam adalah yang paling disenangi oleh walang sangit dewasa jantan. Selanjutnya pada uji ketertarikan dan analisis kromatografi dapat ditarik kesimpulan di bawah ini: (1) Ada perbedaan ketertarikan antara walang sangit dewasa jantan dengan yang betina terhadap kepiting yang membusuk pada hari keenam, yaitu walang sangit dewasa jantan tertarik sedangkan yang betina tidak tertarik; (2) Ketertarikan walang sangit dewasa jantan dipengaruhi oleh macam bahan yang membusuk, darah sapi yang membusuk paling disenangi diikuti oleh keong emas (kepiting dan bekicot), dan daging iga sapi; dan (3) Ada perbedaan macam dan komposisi senyawa volatil yang dihasilkan oleh darah sapi, keong emas, kepiting, bekicot, dan daging iga sapi. Senyawa volatil yang dihasilkan berkisar antara enam sampai sembilan macam yaitu karbon dioksida, metanol, etanol, aseton, dimetil sulfida, amoniak, asam asetat, dimetil disulfida, dan satu lagi tidak teridentifikasi.

Disarankan untuk dilakukan penelitian lanjutan dengan tujuan mengetahui fungsi masing- 
masing senyawa volatil baik secara tunggal maupun kolektif terhadap ketertarikan walang sangit.

\section{SANWACANA}

Penulis mengucapkan banyak terima kasih kepada Dr. Ir. Edhi Martono dan Ir. Santo Sujono atas bimbingan dan pengarahannya selama penelitian ini berlangsung.

\section{DAFTAR PUSTAKA}

Ahmad, B. 1996. Pengaruh Pemberian Residu Kubis dan Solarisasi Tanah terhadap Penyakit Layu Sklerrotium pada Kedelai. Tesis $S_{2}$. (tidak dipublikasikan) Program Studi Fitopatologi, Jurusan Ilmu-ilmu Pertanian, Program Pascasarjana Universitas Gadjah Mada, Yogyakarta. 53 hlm.

Baehaki, S.E. 1985. Berbagai Serangga Tanaman Padi. Penerbit Angkasa, Bandung: 109 - 14.

Dodge, K.L., P.W. Price, J. Kettunen \& J. Tahvanaien. 1990. Preference and performance of leaf beetle Dysonicha pluriligata (Coleoptera: Chrysomelidae) in Arizona and comparison with beetle in Finland. Environmental Entomology 19(4): 905-950.

Frazier, J.L. 1985. Nervous system: sensory system. In M.S. Blum (Ed.); Fundamentals of Insect Physiology. A Wiley-Interscience Publication, John Wiley and Sons, New York. Pp 287 - 353.

Fuchs, A. \& R. Schoder. 1983. Agent for control of animal pests. In K.H. Buchel (ed.), Chemistry of Pesticides (Translated by G. Holmwood). A WileyInterscience Publication, John Wiley \& Sons, New York: 9-321.

Gamliel, A. \& J.J. Stapleton. 1993. Characterization of antifungal volatile compound evolved from solarized soil amended with cabbage residues. The American Phytophatological Society 83(9): 899-905.

Greany, P.D. \& K.S. Hagen. 1981. Prey selection. In D.A. Nordlund, R.L. Jones \& W.J. Lewis (eds.), Semiochemicals: Their Role in Pest Control. A WileyInterscience Publication, John Wiley \& Sons, New York: 121-132.
Heath, R.R., P.J. Landolt, B. Dveben \& B. Lenezewski. 1992. Identification of floral compounds of night blooming jessamine attractive to cabbage looper moths. Environtmental Entomology 21(3): 854-859. 00

Iwahashi, O., T.S. Syamsudin-Subahar \& S. Sastrodihardjo. 1996. Attractiveness of methyl eugenol to the fruit fly Bactrocera carambolae (Dipetra: Tephritidae) in Indonesia. Annal of Entomological Society of America 89(5): 653-660.

Kalshoven, L.G.E. 1981. The Pests of Crops in Indonesia. Revised by van der Laan. P.T. Ichtiar Baru-Van Hoeve, Jakarta, pp. 101 - 8.

Linderman, R.G. \& R.G. Gilbert. 1975. Influence of volatile of plant origin on soil-borne plant pathogens. In G.W. Bruehl (ed.), Biology and Control of SoilBorne Plant Pathogens. The American Phytophatologycal Society, St. Paul, Minnesota: 9099.

Lockwood, J.A. \& R.N. Story. 1987. Defensive secretion of the southern stink bug (Hemiptera: Pentatomidae) as an alarm pheromone. Annal of The Entomollogical Society of America 80(5): 687-691.

Martono, E. 1994. Handout Toksikologi Insektisida (tidak dipublikasikan). Program Studi Ilmu Hama Tumbuhan, Jurusan Ilmu-ilmu Pertanian, Program Pascasarjana Universitas Gadjah Mada, Yogyakarta. $75 \mathrm{hlm}$.

Nordlund, D.A. 1981. Semiochemicals: a review of the termionology. In D.A. Nordlund, R.L. Jones \& W.J. Lewis (eds.), Semiochemicals: Their Role in Pest Control. A Wiley-Interscience Publication, John Wiley \& Sons, New York: 79-96.

Oka, I.N. 1996. Pengendalian Hama Terpadu dan Implementasinya di Indonesia. Gadjah Mada University Press, Yogyakarta. $423 \mathrm{hlm}$.

Pollet, A. \& Nasrullah. 1994. Penggunaan Metode Statistik untuk Ilmu Hayati. Gadjah Mada University Press, Yogyakarta. $423 \mathrm{hlm}$.

Prijono, D. 1988. Pengujian Insektisida, Penuntun Praktikum (tidak dipublikasikan). Jurusan Hama dan 
Penyakit Tumbuhan Fakultas Pertanian IPB, Bogor. 144 hlm.

Robinson, T. 1991. The Organic Constituens of Higher Plants, $6^{\text {th }}$ ed. Diterjemahkan oleh K. Padmawinata. Penerbit ITB, Bandung. 367 hlm.

Roelofs, W.L. 1981. Attractive and agregating pheromones. In D.A. Nordlund, R.L. Jones \& W.J. Lewis (eds.), Semiochemicals: Their Role in Pest Control. A Wiley-Interscience Publication, John Wiley \& Sons, New York: 215-235.

Singleton, G.R. \& D.A. Petch. 1994. A Review of the Biology and Management of Rodent Pests in Southeast Asia. Australian Centre for International Agricultural Research, Technical Report 30, Canberra. 65 pp.

Sihono, A.A. 1997. Ketertarikan Walang Sangit (Leptocorisa oratorius F.) terhadap Bau-bauan Busuk. Skripsi $S_{1}$. (tidak dipublikasikan). Fakultas Pertanian Universitas Gadjah Mada, Yogyakarta. 28 hlm.

Solikhin \& E. Martono. 1997. Daily periodicity of rice bug (Leptocorisa oratorius F.) attendence in response to decaying crab. Indonesian Journal of Plant Protection 3(2): 67 - 71.

Southwood, T.R.E. 1978. Ecological Methods. $2^{\text {nd }}$.ed. Chapman and Hall, New York. 524 p.
Srivastava, A.S. \& H.P. Saxena. 1964. Rice bug Leptocorisa varicornis Fabricornis and allied species. In M.D. Pathak (Ed.), The Major Insect Pests of Rice Plant. The John Hopkins Press, Baltimore: 525 520.

Steel, R.G.D. \& H. Torrie. 1980. Principles and Procedures of Statistics. A Biometrical Approach. International Edition. 2nd ed. McGraw-Hill Kogakhusa Ltd., Tokyo. 633 pp.

Suhardi. 1996. Pengalaman kegiatan setelah SLPHT. Laba-laba 23: 1-4.

Valencia, S. \& E.A. Heinrich. 1982. Mass rearing of rice stink bug. International Rice Reseasrch Newsletter 7(2): 12 - 13.

Vinson, S.B. 1981. Habitat alocation. In D.A. Nordlund, R.L. Jones \& W.J. Lewis (eds.), Semiochemicals: Their Role in Pest Control. A WileyInterscience Publication, John Wiley \& Sons, New York: 51-77.

Weseloh, R.M. 1981. Host location by parasitoids. In D.A. Nordlund, R.L. Jones \& W.J. Lewis (eds.), Semiochemicals: Their Role in Pest Control. A WileyInterscience Publication, John Wiley \& Sons, New York: 79-96. 